\title{
Accounting For Agricultural Products: US Versus IFRS GAAP
}

Treba Marsh, Stephen F. Austin State University, USA Mary Fischer, University of Texas at Tyler, USA

\begin{abstract}
Currently there is a mix of accounting guidance for agriculture producers in the US that is both GAAP including Accounting Statement Codification 905 and non-GAAP financial guidelines. Should the US adopt International Financial Reporting Standards (IFRS), this guidance would be replaced with International Accounting Standard (IAS) 41 - Agriculture.

This study identifies systematic differences between the US and International accounting and reporting for agricultural assets and products. The study also finds that international and US agricultural accounting recognition and reporting guidance result in dissimilar reporting due to guidance interpretation. Valuation variances and definition differences including the requirement to change the agricultural asset recognition method from historical cost to fair value continue to be the basis of major reporting differences. Current US guidance on recognizing and reporting agricultural assets is more conservative than the international guidance. Overall, the US agricultural recognition and reporting guidance contains less information and is therefore less beneficial to financial statement users.
\end{abstract}

Keywords: Agricultural Accounting and Reporting; US ASC 905; IAS 41; Fair Value

\section{INTRODUCTION}

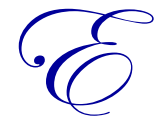

ven though agriculture is important to the global economy accounting standard setters have paid little or no attention to accounting for agriculture products. There was no uniform system of financial reporting for agriculture producers in the United States (US) prior to the farm crisis in the 1980s (Barney 2010, 8) as the industry was focused on production, marketing, or tax reporting rather than decision-making. In fact, generally accepted accounting principles (GAAP) accounting guidance typically ignored or exempted agricultural activities.

Currently accounting guidance for US agriculture producers is based on Financial Accounting Standards Board (FASB) Codification 905 (FASB 2009a). Should the US adopt International Financial Reporting Standards (IFRS), this guidance would be replaced with International Accounting Standard (IAS) 41 - Agriculture (IASB 2000). This study reviews and illustrates current US and international accounting recognition and reporting for agriculture products and biological assets. The study also discusses the advantages and disadvantages of adopting the international guidance.

\section{US AGRICULTURE ACCOUNTING}

The 1980 farm crisis prompted the American Institute of Certified Public Accountants (AICPA) to develop Statement of Position (SOP) 85-3 (AICPA 1985) guidance for accounting by agricultural producers and cooperatives for inventory, development costs and product delivery. The guidance was well received by agriculture producers in all forms of business, from sole proprietorship family farms to publicly held corporations. Subsequently, agricultural reporting consistency became expected rather than the exception. 


\section{GAAP Guidance}

US agriculture recognition and reporting guidance GAAP is governed by Accounting Statement Codification (ASC) Topic 905 (FASB 2009a). Although FASB did not issue a specific accounting standard for agriculture activities prior to the ASC, two standards were considered guidance in addition to SOP 85-3. Those two standards were SFAS No. 144 Accounting for the Impairment or Disposal of Long-lived Assets (FASB 2001) and SFAS No. 157 Fair Value Measurements (FASB 2006). ASC developed Topic 905 Agriculture, based upon SOP 85-3 guidance, that became the highest level GAAP (FASB 2009a).

ASC Topic 905 Agriculture presents an overview, scope, glossary, and other background material for each subtopic guidance, but does not provide any historical background, due process discussion, illustrations for other than cooperatives, or a summary of the accounting and reporting requirements. The subtopics within Topic 905 include information on financial statements, receivables, investments, inventory, fixed assets, liabilities, equity, revenue recognition, and cost of sales.

The more informative sections within the Topic coverage are the inventory and fixed assets Subtopic sections. These two sections identify guidance on whether agriculture assets are treated as goods for sale or as longlived assets. The guidance provides recognition criteria that can result in reporting dilemmas. The following are specific US agricultural GAAP guidance for reporting inventory that create concerns.

\section{Rearing Animals}

All direct and indirect costs of rearing animals are accumulated until the animals reach maturity and are transferred to a productive function. All direct and indirect development costs of animals raised for sale are accumulated, and the animals are accounted for at the lower of cost or market (LCM) until they are available for sale. This guidance creates problems due to the inconsistent determination of when an animal reaches maturity including age, weight, and the ability to reproduce.

\section{Animals Held for Sale}

Agricultural producers report animals available for sale either:

a. At the lower of cost or market (LCM)

b. In accordance with established industry practice at sales price, less estimated costs of disposal when all of the following conditions exist:

- There are reliable, readily determinable, and realizable market prices for the animals;

- The cost of disposal is relatively insignificant and predictable; and

- The animals are available for immediate delivery (FASB 2009a).

GAAP requires producers to record assets at LCM until they are available to sale. The question becomes what value would a producer assign to a newborn animal. According to ASC 905, the value would be LCM since the animal was born on the property. What costs are associated with the infant animal at this point of the cycle? At the time of birth, the cost of feed and boarding would be allocated to the mother animal that produced the newborn. Thus, the assigned value using LCM value for the newborn would be zero. For the first 3 to 10 months of an infant's life cycle, any cost associated with the newborn would be the boarding costs. This presents a valuation issue as ASC 905 guidance recognizes three month old calves at zero on the balance sheet when in the Western US 3 to 6 month old calves have a fair market value of $\$ 200$ to $\$ 300$ or higher (www.decaturlivestockmarket.com).

Under ASC 905 requirements, most agriculture assets are valued at LCM value. However, exceptional cases exist in which it is not practicable to determine an appropriate cost basis for the product. A market basis is acceptable if the product meets all of the following criteria:

- $\quad$ They have immediate marketability at quoted market prices that cannot be influenced by the producer;

- They have characteristics of unit interchangeability; and

- They have relatively insignificant costs of disposal. 
The accounting basis of those inventories is their realizable value, calculated on the basis of quoted market prices less estimated direct costs of disposal (FASB 2009a).

If an agricultural product or animal is classified as available for sale, the ASC allows producers to use a fair market value approach rather than the LCM inventory classification recognition. Producers wanting higher depreciation expense and lower taxable income may feel the need to reclassify the financial statements and recognize cattle as held available for sale. This causes problems for the financial statement user determining whether the producer is reporting products as available for sale to increase the reporting value, or whether the assets are actually for sale.

At the point that breeding and production animals reach maturity, any accumulated development costs less any estimated salvage value, must be depreciated over each animal's estimated productive life (FASB 2009a). Immature animals are not considered to be in service until they reach maturity, at which time their accumulated costs become subject to depreciation (FASB 2009a).

\section{Multiple Products}

Some production animals produce more than one product. For example, sheep produce lambs, wool, and meat; dairy cattle produce milk, calves, and meat. The primary products are lambs and milk, whereas the secondary products are typically wool and calves. Costs may be allocated as either joint products or by-products depending on the estimated relative values of each. In most instances the meat, or slaughter value, of the production animal is considered salvage. The accounting recognition is determined by the amounts anticipated to be received for each product. These amounts are significantly affected by the breeding, production, and marketing practices of the producer which impacts comparability of financial data among producers.

\section{Non-GAAP Guidance}

In 1997, the Farm Financial Standards Council (FFSC) released a non-GAAP Financial Guidelines for Agricultural Producers (FGAP). Although the FASB did not participate in creating the guidelines, the FASB did allow the use of detailed citations within the FGAP to explicitly illustrate where the FGAP deviated from GAAP. The FGAP is a set of guidelines on how to present farm information fairly when preparing information for the use of agricultural lenders and investors. There are seven significant differences between GAAP and FGAP including the following.

1. $\quad$ FGAP allows market valuation of assets.

2. Full absorption cost for valuation of raised breeding livestock.

3. Net realizable valuation of inventory (other than raised breeding livestock).

4. $\quad$ FGAP allows combined financial statements with personal items.

5. Modified cash-basis used for the income statements.

6. $\quad$ Recommends a alternate calculation for deferred taxes.

7. FGAP recognized two formats for the income statement including a value of farm products rather than a cost of goods sold section.

The FFSC also produces the Management Accounting Guidelines for Agricultural Producers (2012) that is subject to ongoing updating and reviews for the continual monitoring of financial issues that are relevant to agriculture. These guidelines include 21 financial ratios and measures that specifically address farm management and is available online.

Advocates of the adoption of international accounting guidance suggest that a single set of accounting standards would benefit all participants in the capital markets and enable investors to compare and translate financial results more easily. While the FASB and International Accounting Standards Board (IASB) conceptual frameworks are quite similar, evasive differences may cause differences in financial reports produced using international guidance (Plumlee 2010). A not so subtle difference between the IFRS and US accounting recognition and reporting is the accounting guidance for agriculture products and assets. 


\section{IASB - IAS 41 AGRICULTURE}

An international standard dedicated exclusively to agriculture was issued by the IASB in 2000, IAS 41 Agriculture (IASB 2000). The guidance applies to biological assets, agricultural products at the point of harvest, and government grants received for agriculture activities.

IAS 41 makes a distinction between biological assets and agricultural products. The guidance does not apply to agricultural land or intangible assets as these items are covered by other guidance. IAS 41 also does not apply to the products after harvest. For example, the guidance addresses the planting and caring for coffee trees plus the harvesting of the coffee beans. However, processing the beans into coffee powder is excluded as it is considered inventory.

The following table displays items included and excluded from the IAS 41 guidance.

Table 1

Assets And Products Covered By IAS 41

\begin{tabular}{|l|l|l|}
\hline \multicolumn{1}{|c|}{ Biological assets } & \multicolumn{1}{|c|}{ Products } & Excluded products resulting from harvest \\
\hline Sheep & Wool & Yarn, threads, carpets \\
\hline Plantation trees & Felled trees i.e., Logs & Boards, plywood, rubber \\
\hline Plants and shrubs & Cotton & Threads, cloth \\
\hline & Sugar cane & Sugar, molasses \\
\hline & Leaves & Tea, tobacco \\
\hline Dairy cows & Milk & Ice cream, cheese \\
\hline Stocker animals & Calves, carcasses & Steak, hamburger \\
\hline Pigs & Carcasses & Sausages, cured ham, bacon \\
\hline Chickens and turkeys & Eggs, carcasses & Meat for consumption \\
\hline Vines & Grapes & Wine \\
\hline Fruit trees & Picked fruit & Processed fruits \\
\hline
\end{tabular}

IAS 41 introduces a model of fair value to agricultural accounting in contrast to prior reporting that used the historical cost basis. The guidance defines fair value as the amount for which an asset could be exchanged, or a liability settled, between knowledgeable, willing parties in an arm's length transaction (IASB 2000). This differs from the US ASC 820 fair value definition that defines fair value as the price that would be received to sell the asset or amount paid to transfer a liability in an orderly transaction between market participants at the measurement date (FASB 2009b). IASB resolved the difference by revising IFRS 13 standard on fair value measurement and disclosure effective January 2013 (IASB 2011).

Researchers that study fair value measurement in agriculture financial reporting argue that the valuation change creates negative issues for the agriculture sector (Argiles et al. 2011). However according to Barth et al. (2001) and Landsman (2007), fair value-based information is more relevant than historical cost-based information.

The literature contains extensive studies that analyze the impact of implementing IAS 41 in various countries and industries ( Arigles and Solf 2001; Booth and Walker 2001; Elad 2004; Elad and Harbohn 2011; Lefter and Roman 2007; Mates and Grosu 2008; PriceWaterhouseCoopers 2009). An issue highlighted in the research is IAS 41 has generalized fair value measurement for all biological assets even though not all assets appreciate and are ultimately sold which can result in misleading financial statement information. Another issue is the lack of a systematic system of determining fair value which can lead to differences in earning quality in the agriculture sector (Aryanto 2011).

IAS 41 guidance deals with the recognition and recording of the transformation of biological assets that include any living plant or animal. Biological transformation is defined as the process of growth, aging, production, or procreation of the biological asset. Recognition of biological assets occurs when the organization controls the assets as the results of a prior activity; future economic benefits are probable; and the asset fair value or cost can be measured. 
Inherent within the guidance are several concerns including the revenue recognition and income measurement, accretion, income statement format, and international comparability.

\section{IAS 41 Concerns}

Revenue recognition and income measurement

The first issue with IAS 41 is revenue recognition and income measurement. IAS 41 Section 7 emphasizes that biological transformation leads to the following results:

- $\quad$ Modifications of the asset through growth by increasing the quantity or improving the quality.

- Degeneration of the asset by decreasing quantity or deteriorating the quality.

- $\quad$ Reproduction of the asset by creating additional living animals and plants.

- $\quad$ Obtaining new agricultural products such as latex, coffee beans, wool, or eggs.

Biological transformation comprises the processes of growth, degeneration, production, and procreation that cause qualitative or quantitative changes in a biological asset. When biological assets are sold, the physical changes that have happened to the assets are valued at fair value. This fair value calculation is used in the income statement when the asset is sold. If fair value cannot be determined, then a comparable asset, or the most recent market price, is used to determine fair value.

IAS 41 Section 18 directs fair value should be based on the following points, without any prescribed hierarchy.

- The most recent market prices of some similar assets, providing that since then no relevant modification of the economic circumstances took place;

- $\quad$ The market prices for similar assets, the difference being treated through adjustments;

- Branch standards, where the value is determined through recalculated production measures, such as the value of the cattle expressed as kilograms of meat.

If fair value cannot be determined using any of those criteria then present value of future cash flows may be used.

These criteria lead to inconsistent valuation within and among countries and industries. Without extensive disclosures, financial information transparency is not available (Elad and Harbohn 2011).

\section{Appreciation}

The most controversial part of IAS 41 is the requirement that fair value increases or decreases, less estimated point-of-sale costs, be recognized as revenues or expenses in the income statement for the financial year in which the change occurs. That is, revenue is recognized during the growth or maturation of the product rather than when the product is sold.

Biological assets may be sold at any time during their growth. For example, cattle or timber can be sold any time at any age at a given market price. However, older cattle or timber typically have higher market prices. For example, older teak trees command a higher price than saplings. Under the appreciation concept, the asset's economic benefit increases during the accounting period and revenue is recognized without having to be realized based on the premise that realization is certain and only a matter of time before it is achieved.

Professional accounting bodies have openly criticized the appreciation recognition because most believe that being able to recognize profits before the assets are sold is not prudent (Elad 2004) and that the recognition leads to earnings volatility. Another concern is the tax implication of being able to recognize appreciation as the recognition provides incorrect and inconsistent financial report information (Elad and Herbohn 2011). 
Income statement display

IAS 41 does not specify whether it prefers the natural classification or function approach. Components within the income statement may be presented by function performed i.e., production, administration or distribution costs, or by the nature of the expense i.e., wages, raw materials or depreciation. The natural classification approach reports only total cost for each item of expense as opposed to the components of the costs that relate to a specific product or cost center. Thus unlike the function approach, the natural classification approach does not allow the disclosure of cost of goods sold. Many believe this avoids conflict with IAS 1 (IASB 2009) which permits two income statement formats for a combined comprehensive income presentation or two separate statements, i.e., basic operating income statement and separate comprehensive statement that combines operating and nonoperating activities.

The inclusion of unrealized gains and losses of biological appreciation or decrease in the income statement using the natural classification approach can result in earnings volatility. IAS 41 has another issue with the natural classification approach because it has language issues. For example, in France the term gross profit has a different meaning that relates only to the margin on goods purchased from external resources for resale (Mates and Grosu 2008). It does not relate to the internal production of the company as it does in other countries. Intermediate consumption is another term that has several meaning in different countries. The United Nations Statistics Division System of National Accounts (SNA 2012) defines intermediate consumption as the value of the goods and services consumed as inputs by a production process, excluding fixed assets whose consumption is recorded as consumption of fixed capital. In France, intermediate consumption refers to the recognition of value added (Elad and Herbohn 2011).

Interviews of international agricultural representatives find that IAS 41 reporting demands a lot of extra work. This highlights the auditor's role in policing the application of the accretion recognition which in some cases result in disagreements between management and auditors (Aryanto 2011, Elad and Herbohn 2011).

Another IAS 41 issue is international diversities in regards to income measurement and financial reporting. Several countries and sectors have their own view of the agricultural guidance which make uniformity difficult if not impossible. One important argument in support of IAS 41 is that in a good biological asset market fair market accounting can be more meaningful than historic-cost accounting. However, there are major impediments to international accounting. For example, a major issue that can initiate the demise of reporting models used by developing nations is the reliability of attaining the fair market value of biological assets. For example, in many tropical countries the fair value determined by the market authorities does not reflect the fair value of commodities. Not everyone accepts that the world market price (fair value) of crops is a price that fully reflects their value (Aryanto 2011).

The revaluation of biological assets on an annual basis is a concern as the determination could prove costly and time consuming as well as create inconsistencies in terms of associated holding gains or losses. And then there are the issues that relate to the implementation of IAS 41. For example in the forestry industry in tropical countries, IAS 41 would be difficult to implement as large primary forest exist rather than commercial tree plantations (Jansson and Fagerstrom 2011).

\section{REPORTING DIFFERENCES - US VERSUS INTERNATIONAL}

The main difference between US agricultural reporting and IAS 41 is reporting the fair value for agricultural assets and products as inventory. US GAAP allows the option to disclose their property, plant and equipment assets, biological assets included, at fair value. However, once elected, the entity may not revert to historical cost values. Historical costs are widely used because of the difficulty of determining a fair value of biological assets, as many do not have a liquid market, or may be valued lower than the historical cost. Neither US GAAP or Non-GAAP guidance allows appreciation valuation for agricultural products. This contrasts to IAS 41 that requires the use of fair value reporting for purchased as well as produced biological assets. The use of fair value reporting has invoked a mixed response from the users of agricultural financial statements. 


\section{Recognition Advantages}

Miller and Bahnson (2009) propose a valid argument for fair value reporting of agriculture as directed in IAS 41. They contend that US agricultural producers issue meaningless financial statements. The entity then provides financial information on an estimate of the current value of the assets, liabilities and equity as supplemental information. Both presentations include disclaimers that precipitate questions from lenders and auditors about the information. Using fair value as a basis for the financial information valuation resolves the reporting inconsistency as the financial statement information has little connection with reality (Miller and Bahnson 2009, 17). They also argue that agriculture could be considered a specialized industry with its own misnomers and quirks but fair value recognition would be helpful.

\section{Reporting Disadvantages}

Under IAS 41 biological assets are no longer recognized as depreciable property and are revalued at each balance sheet date. Regular assets, such as property, plant, and equipment, have the option of being reported at fair value, but it is not mandatory (IASB 2003). A gain or loss resulting from these fair value valuations flows through the profit or loss of the company to the company's income statement unlike US guidance that continues to recognize biological assets as depreciable property assets.

Prior to IAS 41, industry practice booked the trees at their historical cost, capitalized any costs to put the trees in service (plant), and depreciated the trees over their useful life. Thus the industry practice was concrete as it was verifiable, auditable, and understandable. The use of fair value to report the value of biological assets has deviated from fundamental accounting principles and created financial statements that rely on estimates and opinions (George 2007). George (2007) argues that in place of actual historical costs, we now have the malleable notion of fair value, which is often a matter of opinion rather than hard evidence. This undermines accounting information, makes it difficult to express an audit opinion, creates confusion, initiates litigation, and encourages white-collar crooks (George 2007, 80).

Another disadvantage of fair value recognition comes from the changes in realized value passing through profit and loss on the income statement. The application of IAS 41 results in very substantial unrealized gains and losses passing through the income to produce a completely false idea of results that encourages a dividend at odds with the cash flow needed to support the disbursement (George 2007, 81). Other accountants and auditors believe that the requirement to value biological assets at fair value is unduly burdensome (Elad and Herbohn 2011, 88) and leads to the continued use of historical cost and a variety of proxies for fair value. Thus, fair value recognition is unlikely to enhance comparability.

\section{CONCLUSION}

This study identifies systematic differences between the US and International accounting and reporting for agricultural assets and products. The international and US agricultural accounting recognition and reporting guidance results in dissimilar information due to guidance interpretation. IAS 41 is an effort to improve comparability of agricultural financial statement. The basis of major reporting differences are valuation variances and definition differences.

Current US guidance on recognizing and reporting agricultural assets is more conservative than international guidance. Overall, the US agricultural recognition and reporting guidance contains less information and is therefore less beneficial to financial statement users.

\section{AUTHOR INFORMATION}

Treba Marsh, DBA, CPA, Stephen F. Austin State University, P. O. Box 13005, Nacogdoches, TX 75962. Dr. Marsh is Professor of Accounting in the Gerald W. Schlief School of Accountancy at Stephen F. Austin State University. Her research interests include state and local public finance, financial accounting, internal controls and public budgeting. E-mail: tmarsh@sfasu.edu (Corresponding author) 
Mary Fischer, PhD, CGFM, University of Texas at Tyler, 3900 University Blvd., Tyler, TX 75799. Dr. Fischer is Professor of Accounting in the College of Business \& Technology at the University of Texas at Tyler. Her research interests include financial accounting, nonprofit and governmental organizations, auditing and accounting education. E-mail: mfischer@uttyler.edu

\section{REFERENCES}

1. American Institute of Certified Professional Accountants (AICPA). (1985). Statement of Position 85-3 Accounting by Agricultural Producers and Agricultural Cooperatives. AICPA: New York.

2. Argiles, J. M., J. G. Garcia-Blandon \& T. Monllau. (2011). Fair value versus historic cost-based valuation for biological assets: Predictability of financial information. Spanish Accounting Review 14 (2): 87-113.

3. Argiles, J. M. \& E. J. Solf. (2001). New opportunities for farm accounting. European Accounting Review 10 (2): 361-383.

4. Aryanto, Y. H. (2011). Theoretical Failure of IAS 41: Agriculture. http://ssrn.com/abstract=1808413

5. Barney, D. K. (2010). Financial reporting in agriculture. Advances in Management (January) 3 (1): 7-12.

6. Barth, M. E., W. H Beaver, \& W. R. Landsman. (2001). The relevance of the value relevance literature for financial accounting standard setting: Another view. Journal of Accounting and Economics 31, 77-104.

7. Booth, B. \& R. Walker. (2001). Valuation of SGARAs in the wine industry: Time for sober reflection. Australian Accounting Review 11 (23): 52-60.

8. Decatur Livestock Market. (2012) Market Report www.decaturlivestockmarket.com

9. Elad, C. (2004). Fair value accounting in the agricultural sector: Some implications for international accounting harmonization. European Accounting Review 13 (4): 621-641.

10. Elad, C. \& K. Harbohn. (2011). Implementing Fair Value Accounting in the Agriculture Sector. The Institute of Chartered Accountants of Scotland. Edinburgh: Scotland.

11. Farm Financial Standards Committee (FFSC). (2012). Management Accounting Guideline for Agriculture Producers. www.ffsc.org. Farm Financial Standards Council; Menomonee Falls, WI.

12. Financial Accounting Standards Board (FASB). (2001). Financial Accounting Standard No. 144 Accounting for the Impairment or Disposal of Long Lived Assets. Superseded by Accounting Standard Codification 360 Property, Plant and Equipment. FASB: Norwalk, CT.

13. _ (FASB). (2006). Financial Accounting Standard No. 157 Fair Value Measurement. Superseded by Accounting Standard Codification 820 Fair Value Measurements and Disclosure. FASB: Norwalk, CT.

14. (FASB). (2009a). Accounting Standard Codification Section 905 Agriculture. FASB: Norwalk, CT.

15. _ (FASB). (2009b). Accounting Standard Codification Section 820 Fair Value Measurements and Disclosure. FASB: Norwalk, CT.

16. Financial Guidelines for Agricultural Producers (FGAP). (1997). Financial Guidelines for Agricultural Producers. Farm Financial Standards Council; Menomonee Falls, WI.

17. George, M. S. (2007). Why fair value needs felling. Accountancy 139 (1365): 80-81.

18. International Accounting Standards Board (IASB). (2000). International Accounting Standard (IAS) 41 Agriculture. IASB: London, UK.

19. _ (IASB). (2003). International Accounting Standard (IAS) 16 Property, Plant and Equipment. Reissued. IASB: London, UK.

$20 . \quad$. (IASB). (2009). International Accounting Standard (IAS) 1 Presentation of Financial Statements. Revised. IASB: London, UK.

21. (IASB). (2011). International Financial Reporting Standard (IFRS) No. 13 Fair Value Measurement. IASB: London, UK.

22. Jansson, A. M. \& A. Fagerstrom. (2011). Accounting for forest assets: The case of IAS 41 and fair value. Proceedings of Business and Information. Bangkok, July $4-6$.

23. Landsman, W. R. (2007). Is fair value accounting information relevant and reliable? Evidence from capital market research. Accounting and Business Research (Special Issue) 19-30.

24. Lefter, V. \& A. G. Roman. (2007). IAS 41 Agriculture: Fair value accounting. Theoretical and Applied Economics Review 5: 15-22.

25. Mates, D. \& V. Grosu. (2008). Evaluating and recognizing biological assets and agricultural activities according to IAS 41. Agronomie 5: 457-462. 
26. Miller, P. \& P. Bahnson. (2009). It's not just academics who see value in fair value accounting. Accounting Today 23 (12): 16-17.

27. Plumlee, M. (2010). International Financial Reporting Standards. Printice Hall: New Jersey.

28. PriceWaterhouseCoopers. (2009). A Practical Guide to Accounting for Agricultural Assets. PWC: www.pwc.com/ifrs

29. United Nations Statistical Division - System of National Accounts (SNA). (2012). Glossary. http://unstats.un.org/unds/nationalaccount/glossresults.asp?gID=286 
NOTES 